\title{
The "sanctity" of marriage - an archaeology of a socio-religious construct: Mythological origins, forms and models
}

\author{
Yolanda Dreyer \\ Department of Practical Theology \\ University of Pretoria
}

\begin{abstract}
The aim of the article is to argue that the sexual difference between female and male should be regarded as soteriologically indifferent. Though a biological reality of being human, sexuality is profoundly influenced by social constructs and the institution of marriage itself is a social construct. In this article the biological and social aspects are taken into account in a theological approach which on the one hand is interested in the relationship between God and human beings, and on the other in the way in which the Bible elucidates sexuality and marriage. The article indicates that the idea of sexual intercourse between a man and a woman as being equal to Godgiven "holy matrimony" has mythological origins. It focuses on these origins and on the multifarious forms of marital arrangements and models.
\end{abstract}

\section{A CRITIQUE OF THEOLOGICAL ESSENTIALISM}

In a recent publication, Creation and covenant: The significance of sexual difference in the moral theology of marriage, Christopher R Roberts (2007), argues for the necessity to focus on the biological sexual difference between man and woman in order to develop a "moral theology" of marriage. Though never explicitly worked out, the theme announced by the title, namely creation and covenant, forms the basic premise of the book. In this respect Roberts builds on the legacy of Karl Barth. ${ }^{1}$ In the last chapter Roberts (2007:185-231) highlights three different approaches to the theological discussion on marriage.

\footnotetext{
${ }^{1}$ For my critque against Barth's view on gender and its application to marriage, see Dreyer (2007a:1493-1521; 2007b:1523-1547).
} 
The first is the work of Graham Ward (1998:52-72) who goes beyond the traditional question of whether marriage is a sacrament or not. He focuses rather on marriage as a linguistic expression of intimacy in relationship. For him, heterosexual marriage is not the only possibility for expressing the intimate relationship between God and human beings. Same-sex relationships, for example, can provide a linguistic possibility of expressing this relationship, because such relationships can also embody values like intimacy, fidelity and unconditional love. The consequence of his argument is that the sexual difference between man and woman is not a prerequisite for God's salvific interaction with people. This view departs not only from the Roman Catholic theology of marriage, ${ }^{2}$ but also from Barthian Protestant theology (see inter alia G C Berkouwer [1962] 1968:72-74, 89-100; John C Bennett 1962:75-77).

The second approach highlighted by Roberts is that of David Matzko McCarthy (1997:371-397; 2001; 2002:200-216). According to the latter, the love and caring which is supposed to be inherent to heterosexual marriage, can also exist in other relationships. His argument implies that marriage as institution can therefore also be available to people in relationships other than heterosexual. His focus is not on sexual difference.

A third approach discussed by Roberts is that of Eugene Rogers (1999; 2004:26-29) for whom procreation should not be deemed central to marriage. Since Luther and Calvin marriage has no longer been considered a "saving grace". Before the Reformation marriage was regarded as the "remedy" for lust and sexual desire (see Francis Schüssler Fiorenza 1991:316). Sexual enjoyment was seen as $\sin$ from which marriage provided salvation. Since the Reformation, it was no longer an either/or. Both sexual enjoyment and marriage were acceptable, though sexual desire was still to be controlled by means of marriage.

For Roberts none of the above approaches is convincing. In his view, the creation of man and woman forms part of the order of creation. This would then mean that sexual difference is of the utmost importance when theologising about marriage. Roberts, building on Karl Barth, who, in turn, builds on Luther, does not see marriage as a sacrament. However, both Luther and Barth regard marriage as part of the order of creation (see Dreyer 2007a:1493-1521; 2007b:1523-1547). Sexual difference is therefore important to Luther and Calvin, as well as to Barth and Roberts when they discuss

\footnotetext{
${ }^{2}$ For the Roman Catholic Church's doctrine of marriage, see (1) texts such as Hugh of St Victor's On the sacraments of the Christian faith (c $1143 \mathrm{CE}$ ), Peter Lombard's Book of sentences (1150 CE), and Thomas Aquinas's Summa Theologicae (C 1265-1273 CE) and the later commentaries on these texts and (2) the church's canon law of marriage (first in Gratian's Decretum in c 1140 cE) (see inter alia Witte 1997:23).
} 
marriage from a theological perspective. Roberts (2007:13-38) shows clearly how the diverse ideas on marriage that were in vogue before the time of Augustine, were forced into a logical system by Augustine (see Roberts 2007:39-77) and how this system determined how marriage was seen within the European tradition up to the Reformation (see Roberts 2007:111-137). The Reformation did not quite succeed in moving beyond Augustine. Roberts' book illustrates this.

In tandem with the Reformers and many Reformed theologians he perpetuates the idea that marriage is "God's will" and that God willed it to be heterosexual. That is why God created man and woman. Roberts does not seem open to the possibility that God may also have created sexual minorities and that sexual intimacy could therefore also be legitimate outside of a heteronormative context. Roberts (2007:171-183) is critical of Pope John Paul II who affirmed that marriage was indeed a sacrament. However Roberts does not proceed to expose the fact that the idea of marriage as a sacrament, which has been prevalent in the Roman Catholic Church since Augustine and especially with Thomas Aquinas (see Roberts 2007:99-109), has implicitly led to marriage being endowed with soteriological power. Within this sphere of thought, sexual desire and the sexual act without the intention of procreation, were seen as a deadly $\sin$ (Augustinus, De bono coniugali 6.6; 8.8; see Kari Elisabeth Børresen [1968] 1981:94-123). The sacrament would then be the medicinum and remedium for these sins.

In this article I enter into a discussion with the views of Roberts. In my opinion marriage should be de-sacramentalised. I regard the sexual difference between female and male as soteriologically indifferent. It is my contention that sexuality, though a biological reality of being human, is profoundly influenced by changing social constructs and that the institution of marriage is itself a social construct. The biological aspect can be approached from a naturalistic perspective. The social aspect can be approached from a humanitarian perspective. Both the biological and social aspects will be taken into account in a theological approach which, on the one hand is interested in the relationship between God and human beings, and on the other hand in the way in which the Bible elucidates sexuality and marriage. Such a multidisciplinary approach presupposes a dialectical theological model. Along with this, I also choose for a hermeneutic of suspicion.

A positivistic epistemology would presuppose a revelational model which would be inclined to deal with Biblical propositions on sexuality and marriage in a literalistic way. According to Marcus Borg (2003:13), such an essentialistic approach is the opposite of a postmodern view of biblical meaning as metaphorical, in other words "more-than-literal", "more-than- 
factual". A literalistic approach will not be able to expose the hidden heteronormativity in patriarchal traditions since biblical times.

A second consequence of such an approach is that heterosexual marriage as an institution will be regarded as unchangeable and ordained by God. This view is basically essentialistic because it sees sexuality as one of the most essential parts of "our understanding of human nature and behaviour" (Lewes 2003:172). An anti-essentialistic, that is a socialconstructionist, approach opposes the idea of a "timeless, universal core which ultimately explains [human] actions" (Ward 1997:136). A postmodern perspective rejects essentialism and replaces its abstract universalising idea of intimate relationships with particularity, which takes people's historical, social and cultural as well as biological orientation into account (cf Stone 2000:235).

Over against Roberts's modernist (essentialist) view I choose to move the biological sexual difference between man and woman from the centre of the theological discussion on marriage. The reason is based on the postmodern insight that social constructs change as paradigm shifts take place. This means that perspectives on sexuality change over time. Through this lens a variety of marital forms and models throughout history can be identified.

Roman Catholicism and Protestantism have taken different routes. In the Roman Catholic tradition marriage is seen as a sacrament. This means that soteriological power is explicitly given to marriage. Protestant theology has descramentalised marriage, but still sees the institution of marriage as a reflection of the kingdom of God. "Holy matrimony" remains a God-given heterosexual ordinance where the difference between maleness and femaleness is essential.

In this article I indicate that the idea of sexual intercourse between a man and a woman, as being equal to God-given "holy matrimony", has mythological origins. A diversity of views on sexuality and marriage existed in early Christianity. The article focuses on the origins and the multifarious forms of marital arrangements and models. Although not elaborated upon in this article, my thesis assumes that it was Augustine (De Trinitate 7.7.10; cf Stammkötter \& Müller 2004:49-52) who merged this diversity into one religious system by means of which people as sexual beings can be saved and become acceptable to God. This one-dimensional soteriological system paved the way for Thomas Aquinas's (see Mackin 1982:32) unchangeable sacrament of "eternal holy matrimony". The Reformers rejected the idea of marriage as a sacrament (see Douglass 1991). Further along this road Karl Barth used marriage as the tool by means of which to establish a connection 
between creation and covenant in his soteriology. Though the Reformers (see Buitendag 2007 with regard to Luther) and Barth (1934-1964, CD III.2.315316) desacramentalised marriage, sexual difference still remained central for them (see Ruether 1978:56).

However, it is my contention that positivism and essentialism, which are embedded in the grand narrative of patriarchal theology, cannot provide a meaningful discourse on sexuality and marriage for postmodern people today, since it is too one-sided and static. Postmodern discourse, on the other hand, is open to plurality, fluidity, ambiguity and welcomes the counternarratives of the marginalized (see Lyotard [1979] 1984; 1989:122-154; 1993). In another study the so-called "postmodern" approaches to the "theology of marriage" to which Roberts refers, will be critically discussed on order to open the door for the option of the theologising about marriage without the essentialist assumption that the sexual difference between female and male is soteriologically significant. To achieve such a goal, the point of departure of this study is that the complicated interconnection between sexuality and marriage has changed. This insight paves the way for the conviction to be argued in the article, namely by taking the mythological origins, forms and models of marriage as institution into consideration, an "archaeology" of its mystified sanctity demurs marriage as merely a socio-religious construct amongst others.

\section{A CRITIQUE OF UNCHANGEABILTY}

\subsection{Tradition and change}

The content of the Bible includes both material based on tradition and faith assertions. The most important tradition-based material forms the basis of the faith propositions. Tradition provides the metaphors and imagery by means of which matters of faith can be communicated. Traditions are social constructs. Traditions keep societies in balance. When traditions change, the social balance is disrupted. Marriage forms are traditions. Marriage is one of those important traditions and models that provide the metaphorical language by means of which faith can be communicated.

Some traditions, such as dress and eating habits, change rapidly, whereas others change so slowly that they seem immutable. Especially traditions regarding identity, sex, language and ethnicity change very slowly. The more fixed traditions which provide the basis for faith, are often deemed so fixed that they are seen as part of the order of creation. This means that they are seen as God-given rather than socially constructed. Because these fixed traditions contribute to the formation of identity, they also help to 
determine social roles. However, though marriage forms did change in Biblical times, social roles did not change. In spite of the changes that occurred, the culture remained patriarchal, which means that men were still mostly the heads of households consisting of women, children and slaves, who were to be obedient in all respects (cf Osiek \& Balch 1997:215-222). The scarcity of textual evidence of the love of women for women should be seen as the result that men were the scribes in antiquity (cf Botéro \& Petschow 1972-5:468; Otto 1996:322-330).

In patriarchal culture procreation was the main purpose of marriage. These traditions and social roles were perpetuated by generation after generation - from Old Testament times (Otto 2007:62) until the Christian era (e.g., Augustinus, De bono coniugali 32.24; see Kearney 1999:48, 56). In Biblical times people did not get married because of mutual attraction, but because their marriage had been arranged by the patriarchs concerned in order to further the interests of both families (see Countryman 2007:144-229). In this way the social identity of the group was protected.

The social dynamics of a patriarchal society which was based on the sexual difference between male and female and the accompanying different social roles on the one hand and pivotal values such as honour and shame on the other hand, was kept in balance by means of hierarchy (see Stegemann \& Stegemann [1995] 1999:361-377). Arranged marriages preserved and perpetuated the patriarchal system.

\subsection{Sexuality and shifting paradigms}

When sexual difference becomes the focus of social dynamics, the consequence is that sexuality, marriage and religion will function in an interconnected way. If the focus changes, both the connections between them and the values attributed to them will change. The values attributed to religion, sexuality, and marriage did change over time, from premodern, to modern, to postmodern contexts. In order to understand how change has come about from biblical times to the present day, it is necessary to investigate the social dynamics of these three concepts and the meanings attributed to them in the different eras of antiquity (see Dreyer 2005:729-751). The social environment of the biblical world can be distinguished in the Eastern Mediterranean (Semitic) and the Western Mediterranean (Greco-Roman) contexts. These contexts first functioned separately. Later they merged because of Hellenisation. ${ }^{3}$ In both these Mediterranean contexts religion, sexuality, and marriage were interconnected, though the values attributed to them, differed

\footnotetext{
${ }^{3}$ For example, in Israelite society textual evidence of affection within intimate relationships occurred only since Hellenistic times, and indication of such affection in Song of Songs should be seen as marginal to societal convention in Israel (cf Müller 1994:375-393).
} 
from the one context to the other. The Old Testament mostly mirrors the Eastern Mediterranean world, whereas the New Testament represents a syncretism of the values of the Eastern and Western Mediterranean worlds.

Present-day Christian faith communities face the consequences of the paradigm shifts that have taken place from biblical times up to the present. The source book of Christianity, the Bible, originated in a premodern world with premodern perspectives on sexuality, religion and marriage. What was understood by these three concepts in antiquity differs quite substantially from how they came to be understood in the Modern Era. Today, evidence points to a radical shift yet again from the Modern to the Postmodern Era. An obvious interconnection between religion, sexuality and marriage no longer exists. If this is the case sexual difference can no longer be central to a theology of marriage. The challenge today is to live with the biblical message of redemption in the presence of God within the context of the faith community, but without blind submission to outdated social constructs. ${ }^{4}$ Conscientisation regarding the mythological origins of the institution of marriage and the changes in marital forms and models as well as a critique of the "sacramental unchangeability" of marriage are therefore necessary.

\section{MYTHOLOGICAL ORIGINS}

In the Bible marriage is used as a metaphor for the relationship between Jahweh and Israel/God and church (Batey 1961:22-24). As to the origins of marriage as metaphor, there are different theories an opinions. An explanation for Hosea's use of marriage as metaphor is that he adopted the easternMediterranean idea of hieros gamos (cf Schlier 1957:264-276), but replaced the goddess or earth with Israel as Jahweh's consort (see Adler 1990:393394).

\footnotetext{
${ }^{4}$ For example, the so-called môt jûmat-formulas ("they should be killed ....") were part of the criminal codes in the Eastern-Mediterranean justice system (see Otto 1994:32-34). These codes were related to those concerning the "pollution" of the God-given land and should be interpreted against the background of a "politics of holiness" (see Borg 1987:86-87). In such a "political" context God's people were separated from gentiles (cf Otto 2007:63-64). The dietary codes about the consuming of "pure" and "impure" meat fall within the same category. These codes are found in the Old Testament specifically within the Pentateuch. The "holiness codes" in Leviticus 18 and 20 deal with sexual relationships. The post-exilic redactor of the Pentateuch positioned these two chapters before and after Leviticus 19 in which reciprocal individual ethics, with the love command as climax, are highlighted (see Otto 2007:61). The instructions in chapters 18 and 20 about sexual intimacies, added by the redactor of the Pentateuch, are analogous to other commands in Deuteronomy (specifically Deut 23:17ff) and to the pre-exilic Covenant Code in Exodus 20:22-23:33 (specifically Ex 22:19). These commands were based in a primordial fashion on creation ordinances (Otto 2007:64). However, it is clear that the môt jûmat-formulas cannot be made applicable to present-day ethical issues (Otto 2007:65).
} 
Aloysius Fitzgerald (1972) argues that in the West Semitic area a city was often seen as a "goddess" who was married to the patron god of the city. Seen against this background it would then be "adultery" if the people of the city were to worship another god. Adler (1990:394-395) points out that such a view would only hold true for monotheistic Israel, since worship of other gods than the patron was tolerated outside of Israel.

Another possible basis for the metaphor of Jahweh's marriage to Israel is found by some in the epigrapha from the $9^{\text {th }}-8^{\text {th }}$ centuries BCE discovered at Kuntillet Ajrud. These texts refer to Jahweh having an "asherah".

Grammarians agree that this cannot be a proper name because of the possesive suffix. Rather it was a common noun referring to an inanimate object. That the asherah in Israelite worship was indeed an inanimate object, is confirmed by texts such as Deuteronomy 16:21 and 2 Kings 17:10. Adler (1990:395) concludes that what is represented here is a "syncretistic phenomenon, a pagan element which entered the worship of JHWH".

Evidence of knowledge of the Sumerian sacred marriage rite was found by scholars in biblical Israel. As the scholars have reconstructed the rite, it was the sexual union of the king and the priestess which represents the connection between the gods and human beings, between heaven and earth (see Bishop 2004:33; cf Human 2007:31). This ritual marriage was to ensure the prosperity of the nation and maybe even provide an heir to the throne who was then regarded as a god-king. Adler (1990:400) doubts, however, that this ritual was really acted out in the manner described by modern scholars. Kramer (1969) points out that the written evidence of the ritual is too varied and even shows some improvisation. A sacred ritual which was imperative for the well-being of the nation, would have had to have been acted out precisely according to the prescriptions. Livingstone (1986; cf Adler 1990:401) notes that deities were normally represented by objects which were in some way connected to them, rather than by people. No mention is made of the possibility of impotence of the king, which would have disrupted the ceremony and what measures should be taken were that to be the case. Given the fact than some kings were old and sick, according to Adler (1990:402) "it seems unlikely that such a king would be entrusted with providing his kingdom with its 'life-force' for the ensuing year .... Therefore, it can be suggested that the sacred marriage rite was dramatized in the cult with symbols of the deities, rather than with their human representatives."

There is sufficient evidence that the idea of hieros gamos in the eastern-Mediterranean fertility cults influenced Israelite culture (see Winter 1987:313-368) and even the Christian understanding of marriage (cf Osiek 2002:32). This confirms that an interconnection between sexuality, marriage 
and religion was prevalent in Israel and early Christianity. This explains why the story of Adam and Eve in paradise was interpreted as the first marriage and became the basis for the theological link between creation and covenant. This also explains why the apostasy of Israel was seen as adultery. Presentday studies have indicated that this Old Testament notion, especially as expressed in Hosea in connection with the Genesis texts, is the most important intertext for the Christian understanding of the union between the church as bride and Christ as the bridegroom in Ephesians 5 (Van DijkHemmes 1989:84; Johnson 1992:430; see Botha \& Dreyer 2007:1248-1269). Polygamous unions in the Old Testament within the context of the fertility cults and the Christian notion of monogamy indicate the existence of a variety of marital forms in antiquity.

\section{A VARIETY OF MARTIAL FORMS}

The two main forms of heterosexual marriage are monogamy and polygamy. Monogamous heterosexual marriage is that of one woman with one man at any given time. Traditionally monogamous heterosexual marriage was meant to last for as long as both spouses were alive. However, given the increase in the rate of divorce and remarriage in recent times the monogamous system of marriage is now often referred to as "serial monogamy" (Belkin \& Goodman 1980:23), which means having different spouses, but one after the other rather than more than one at the same time.

In Western societies - and increasingly for the most part in other societies as well - monogamy has become the prevalent marriage system. As a rule monogamy is the only acceptable one in most societies (Goode 1976:159-167; Belkin \& Goodman 1980:23). However, it has not necessarily been the most preferred form of marriage (Spiro 1956; Goode 1963). Today literature advocating the view that contemporary monogamous marriage is too restrictive for many and that alternative types of intimate relationships should be discussed more widely and made more socially acceptable, abounds (e.g. Libby \& Whitehurst [eds] 1977). According to a study already done in 1949, Murdock showed that only $17 \%$ of the 250 societies investigated regarded monogamy as the preferred form.

Where the number of women and men are fairly equally distributed in a society monogamy could be a practical arrangement. Theoretically there could then be a mate for each person. In a monogamous marriage only two people are responsible for satisfying each other's emotional needs and only two people shoulder the responsibilities of a household (Huse \& Grant 1978). In societies where married people carry a heavy burden of social responsibility, 
such an arrangement is not practical (Weitzman 1970). Where other social institutions assume many of the responsibilities, marriage consisting of only two people becomes more viable (Belkin \& Goodman 1980:24). Marriage as a social institution is therefore not isolated from cultural influences (Stephens 1963) and does not exist separately from other social institutions (Kohn 1969; Queen \& Habenstein 1974).

Polygamy is a marriage form where one person of either sex has more than one spouse. Mostly it is about one man having many wives, but this need not necessarily be the case. There are three subcategories of polygamy: polyandry, polygyny and group marriage (see Stephens 1963).

Polyandry is when one woman is married to two or more men at the same time. This does not occur very frequently (see Murdock 1949, 1957) and when it does, it is in a society where there are more men than women and which is a "severe subsistence economy" (Belkin \& Goodman 1980:24-25). More men providing for one woman and her children is a way to survive in harsh circumstances. It is not the case that many more male babies are born than female ones. In order not to upset the balance of the sexes in such a society it is necessary to get rid of some female children. Female infanticide serves this purpose (cf Osiek \& Balch 1997:65-66). This also keeps the birth rate down and reduces the number of people who have to be fed. It is therefore clear that there is a relationship between the marriage form and the economic and environmental factors prevailing in a society (Belkin \& Goodman 1980:25).

Polyandric marriage can be either fraternal or nonfraternal. In the first case the husbands of the woman are either brothers or classified together and in the second instance they are not related (Belkin \& Goodman 1980:25-26). Though there is not much evidence of this form of marriage, in those that do exist the fraternal variation is more prevalent. Husbands who are brothers or family tend to be less jealous and competitive. The main reason given why polyandry is so rare, is that men do not easily grant another man sexual access to their wife. Belkin \& Goodman (1980:26) do, however, concede that there is not really any evidence to support this assumption. In ancient Mediterranean cultures giving a wife to a visitor for his sexual use was a common way of showing hospitality (Countryman [1988] 1990:30).

Polygyny is the system of marriage where one man is married to two or more women at the same time. This is the most common form of polygamy (Belkin \& Goodman 1980:26). In Murdock's (1949) first study 81\% and in a later study (Murdock 1957) 75\% of societies allowed polygyny. Though polygyny seems to be the preferred form of marriage in those societies where it occurs, monogamy is the form most practiced. According to Belkin \& 
Goodman (1980:26) the reasons for this pertain to matters such as economics and status systems. In order to have multiple wives a man has to be economically strong. Not only does a bride price have to be paid, but he has another mouth to feed. If all the women have a few children, there can be a substantial increase in people for whom food has to be provided. This accounts for the fact that even in societies where polygamy is allowed and preferred, only a few wealthy, mostly older men, can afford more than one wife. Having more wives is therefore a status symbol. Having a higher status can give a man access to scarce resources in the community (Belkin \& Goodman 1980:26). Additional wives are also valued for the extra labour that they provide for the family (Belkin \& Goodman 1980:27).

First wives generally have more status, privileges and authority than the others. The husband is obligated to spend an equal amount of time with all of his wives. Through this measure jealousy is minimised. Another measure to preserve the peace is that each wife normally has her own house. She has her own space where she has the sole authority. This arrangement is not prevalent where the wives are sisters. This is called sororal polygyny (Murdoch \& Whiting 1951). According to Stephens (1963:67) "siblings can better tolerate, suppress, and live with a situation of sexual rivalry than can nonsiblings".

Since the birth rate is fairly equally distributed between male and female, a society where there are many more women than men, does not exist and the sex ratio has to be balanced artificially. One way of doing this is having women marry early while men marry late. Men generally die before women, which means that there are relatively few older men available. In polygynous societies young men rarely have more than one wife. Sometimes they have no wife at all (Belkin \& Goodman 1980:28).

Like polyandry, group marriage is possible, but very rare. It is where two or more men are married to two or more women at the same time (Belkin \& Goodman 1980:28). In Murdock's (1949) study no instances of group marriage were found. However, this phenomenon can be found among certain religious cults and fringe groups (Belkin \& Goodman 1980:28). In group marriage the men have equal sexual access to the women, though a primary couple may sometimes have priority (see Linton 1936). Group marriage, like the other forms of marriage has to do with the sexual, economic and social needs of the people involved (Belkin \& Goodman 1980:28).

When marriage practices in societies all over the world and over the ages are considered, it becomes clear that there is no "one, normal, natural" form of marriage. Crosby $(1976: 88)$ puts it as follows: 
Whether or not monogamy or polygamy is the "natural" thing cannot be resolved by looking at the animal world, for the wolf and the tiny gerbil are monogamous, while many other species are not. The appeal to morality depends entirely on the mores of the society in which the appeal is made ... The appeal to religious authority depends on the religious tradition to which one appeals. The appeal to libidinous drives and desires for justification for multiple mates may reveal more about man's psyche than his libido. The traditions, customs, and mores of a given society together with one's own sense of value and meaning should appear to be the more accurate predictors of "man's essential nature".

\section{A VARIETY OF MARITIAL MODELS}

\subsection{Introduction}

The Western Christian Church has presented four perspectives on marriage: a naturalist, social, contractual and religious perspective (Witte 1997:2-15). From the religious perspective marriage is seen as a spiritual or sacramental union which is regulated by the creed and practices of the faith community. From a social perspective on marriage there are certain social expectations and privileges bound up with marriage, some of which are regulated by law. From a contractual perspective marriage is seen as a voluntary association into which people enter voluntarily and tailor to their own needs. Of the naturalistic perspective presented by the church Witte (1997:2) says: "hovering in the background is a naturalistic perspective that treats marriage as a created institution, subject to the natural laws of reason, conscience, and the Bible".

These four perspectives highlight different aspects of marriage: its religious sanction, communal legitimation, voluntary formation and "natural" origin (Witte 1997:2). The question is whether these four perspectives complement one another or whether one claims supreme authority. Who has the ultimate say over marriage: the church (including God and the Bible), the state, the family or nature? Is the power in the hands of "the church, the state, the marital couple, or God and nature operating through one of these parties?" Witte (1997:2-12) distinguishes five models of marriage in modern Western Christian traditions which will now be briefly discussed.

\subsection{The Roman-Catholic model}

Since the mid-twelfth century the Roman Catholic Church saw marriage simultaneously as a natural, contractual and sacramental matter (see Schillebeeckx 1965). Marriage was "natural" because God created this association between men and women to enable them have children, whom 
they were to raise to love and serve God. The institution of marriage was also seen as a way to control lust (cf Mackin 1982; Francis Schüssler Fiorenza 1991:316). Marriage was seen as "contractual" in the sense that is was based on the mutual consent of a man and a woman and as a contract which was to provide the guidelines for their lifelong relationship of love, service and fidelity. Marriage was also seen as a "sacrament" which Witte (1997:4) describes as follows: "The temporal union of body, soul, and mind within the marital estate symbolized the eternal union between Christ and His Church, and brought sanctifying grace to the couple, the church, and the community." The sacramental perspective was the unifying factor. It brought the religious, natural and social aspects together under the authority of the Church.

Marriage as a "sacrament" presupposes that it is seen as an institution ordained by God and as a part of the order of creation: God created humankind as male and female. The union of the two sexes therefore has religious significance. Participating in a sacrament allows one to experience God's salvific presence. The result of such a theology of marriage is a natural theology. Religious meaning is derived from creation rather than faith. If marriage is seen as a sacrament, it cannot be broken. It is regarded as an unchangeable institution and divorce is prohibited. Marriage as a sacrament is seen as an act of salvation because it serves as "medication" (medicinum) and remedy (remedium) against the "deadly disease" of fleshly lust (concupiscence) which is sex that does not intend procreation (cf Brooten 2003:187, note 11).

The idea of marriage as a sacrament was built on the theology of Augustine and Thomas Aquinas. Their theology put an end to the diversity of opinions regarding sexuality and marriage which was prevalent in the church from the apostolic to the patristic period. The Didache (C $120 \mathrm{CE}$ ) (edited by Audet 1958:226-242; see Berkowitz \& Squitier 1986:107) and the Didascalia Apostolorum (C 250 CE) (tr by Connolly 1929, chap 2, 3, 4, 14; see Witte 1997:19) consists of some of the earliest church laws which have been preserved. These writings, similar to Biblical passages on the matters of sexual conduct and propriety, prohibit among others sodomy, adultery, pedophilia, fornication and commend chastity, celibacy, modesty of dress and the separation of male and female persons when it comes to education or bathing.

From 325 to 451 CE the Christian ethic of marriage and sexuality expanded and developed. At first servants of the church were to be "chaste, heterosexual and monogamous", but by the late fourth century they were to be celibate or lose their clerical office. As far as lay people were concerned, they were to be monogamous and heterosexual. Paul's list of sins was 
expanded to include bestiality, polygyny and polyandry. Widows were not to remarry after the death of their husbands. Christians were not to marry heretics, heathens, people with whom they had fornicated and blood relatives. Marriages should not have taken place during Lent or on holy days (see Scharr \& Wace 1952:11, 46-51, 70, 73, 79, 81-82, 92, 95, 98, 129, 149, 156, 157, 279, 280, 452, 460-462, 569-570, 604-613; Balch \& Osiek 1997). These theachings were reiterated in commentaries and sermons by Church Fathers such as Ambrose, Athanasius, Chrysostom, Clement, Gregory of Nyssa, Jerome and Tertullianus (Witte 1997:19; see Reynolds 1994:121-240).

The early Church Fathers were especially critical of Roman society which tolerated concubinage, transvestism, pederasty, incest, polygamy, abortion, infanticide and child abuse. They were also against marriages that were arranged for economic and political reasons, and of the Roman law that husbands alone could file for divorce. Tertullian, in his works Apologeticus and De Spectaculis (Tertullian, tr by Rendall 1931:32, 35-48, 79, 105, 179, 274281) criticizes such Roman institutions and in Against Marcion (in Roberts \& Donaldson 1885a:294, 385-387) he speaks on procreation as the main purpose of marriage. In The instructor Clement (in Roberts \& Donaldson 1885b:250-253) writes on the proper relations of men and women, on the lawful use of marriage (in Roberts \& Donaldson 1885b:259-263) and in Stromata (in Roberts \& Donaldson 1885b:377-379) on marital goods.

The late Church Fathers steadily moved to a point where celibacy, virginity and chastity were much preferred to any form of intercourse, including that within the marital union (see Witte 1997:20). Ambrose of Milan (in Schaff \& Wace 1952:395) put it as follows: "[T]he virtue of chastity is threefold: one kind that of married life, a second that of widowhood, and a third that of virginity". His clear preference was for the latter.

These early Christian writings did not culminate in a systematic theology of marriage (see Mackin 1982:38-80). Witte (1997:20-22) does however trace the various perspectives on marriage of the natural, spiritual, contractual and social, through the work of the leading Greek Church Father, Chrysostom (345-407 CE) and the leading Latin Church Father, Augustine of Hippo (354-430 CE).

From the natural point of view Chrysostom (see "Sermon on marriage", in St John Chrysostom on marriage and family life, 1986a:81, 85) viewed marriage as created by God for two reasons: chastity (marriage as remedy for desire) and procreation. From the spiritual perspective he thought that marriage should not be demeaned, since to marry in Christ reflects the believer's union with God (see "Homily 20 on Ephesians", in St John Chrysostom on marriage and family life, 1986b:54-55). From the contractual 
perspective he found that marriage should not only be economic contracts, but should be entered into on account of the moral quality of the chosen spouse (see Chrysostom, "Homily on Matthew", in Schaff \& Wace 1952:443444 ) in order to procure "a fellowship for life" (Chrysostom, "How to choose a wife", in St John Chrysostom on marriage and family life, 1986c:89-114). The appropriate order in a household, according to Chrysostom, was that the man was the paterfamilias and that the wife was a "second authority". According to him, "where there is equal authority, there never is peace. A household cannot be a democracy, ruled by everyone; the authority must necessarily rest in one person".

Augustine of Hippo (De civitate Dei XIV.10, 21, 22; in Dyson, R W 1998, Augustine, City of God), combining the natural and spiritual perspectives, saw marriage as a "true and loyal partnership" in which procreation was to be seen as a gift and not as a punishment of sin. From a contractual perspective, he regarded procreation as the purpose of marriage and emphasized the role of witnesses attesting to the union (Augustine, Sermon 1.22, in Schaff \& Wace 1952, 6:253; see also Augustine, De civitate Dei XIV.18). From the social perspective, according to Augustine (De civitate Dei XIX.16) the "ordered agreement of command and obedience" in a household served as an example for the "ordered agreement concerning command and agreement among citizens". From a sacramental perspective, Augustine (On original sin, 39.xxxiv, in Schaff \& Wace 1952-5:251) viewed marriage as a permanent union (connubi sacramentum). However, he never called marriage a sacrament, an instrument of grace. The sacramental model only developed later (cf Witte 1997:22). As a sacramental bond (quoddam sacramentum), marriage symbolized permanent union between Christians (Augustinus, On marriage and concupiscence, 11.x; 19.xvii, in Schaff \& Wace 1952-5:261, 271). Only death could separate married people. Even if the marriage did not produce children, which Augustine regarded as the main purpose of marriage, the union may not be dissolved in order for a spouse to try and have children with someone else.

According to Witte (1997:22), "Augustine's theory of the marital goods of procreation, fidelity and sacrament, was the most integrated Christian theory of marriage offered by the Church Fathers." Augustine did not, however, work out the full legal and theological implications of his theory. His aim was to define Christian marriage clearly in distinction with pagan marriage and Gnostic and other heretical ideas of marriage. Witte (1997:22) summarises the purpose of Augustine's writings on marriage as follows: "He sought to show that Christian marriage was a stable and permanent union. It allowed procreation with one's spouse even if continence was spiritually 
preferable. It demanded fidelity to one's spouse even if procreation was naturally impossible." It seems that the order of priorities was: first celibacy, fidelity in marriage in the second place, and procreation in the third place.

Bernadette Brooten (1996:175-186) critically discusses what is probably the oldest known classification of sexual acts in antiquity. This classification was done by Artemidorus of Daldis in Asia Minor in the 2nd century CE in his work, Oneirokritika 1.78-80 (Van Aarde 2007; cf White 1975). Artemidorus distinguishes between kata nomon, para nomon and para fusin. Kata nomon is sometimes substituted with kata ethos which is translated with "according to custom". Pederasty is placed in this category. Acts such as (male) masturbation, "passive sex" of a woman with a woman, sex with a (male) god, or sex with a corpse, are regarded as para fusin, "against nature" (for the semantic difference beween nomon and fusin, see Winkler 1990). Most probably the use of para fusin in Romans 1:26 was influenced by this (cf Wengst 1987), because Artemidorus's classification dates earlier than the 2 nd century CE (see White 1975).

Augustine (De nuptiis et conupiscentia 20.35) interprets the list of prohibited sexual acts in Romans 1:26-27 as referring to sex that did not have procreation as goal, for example oral and anal sex. He did not add homoerotic sex to this, as his contemporaries did. However, in his work, Epistulae 211.1314 and in De opera monacharum 32. 40 he condemns homoerotic sex. The "unspeakable sin" in Eph 5:12 (ta gar krufē ginomena hup' autōn aischron estin kai legein) he declares to be contra naturam in his work, De bono coniugali 10.11-11.12; 8.8 since it could mean homoerotic sex (vaginal, anal or oral) (see Brooten 2003:181-193 - especially p 187, note 11). According to Augustine (De bono coniugali 17.19) the purpose of marriage is the same "for all people" (in omnibus gentibus), namely to procreate (proles) and fidelity (fides). For Christians it is also about the "holiness of the sacrament" (Augustinus, De bono coniugali 32.24) which for Augustine means that divorce and remarriage while the ex-spouse is still alive, is forbidden (see Augustinus [s a] [1999]:48, 56). Augustine condemns sex for pleasure (conupiscentia) - even within marriage - as fornication, which, along with adultery are regarded by him as mortal sins (Augustinus, De bono coniugali $6.6 ; 8.8$ ). Sex for pleasure, though also $\sin$, is the lesser of the immoralities classified as para fusin.

The only "moral sexuality" is first and foremost celibacy (see De bono coniugali $7.6 ; 8.8 ; 9.9 ; 23.28$ ) and secondly sex within marriage with the purpose of procreation - otherwise marriage partners should refrain from having sex. Though this is the principle laid down by Augustine ( $D e$ bono coniugali 11.12), he does regard other acts which are not classified as "mortal 
sins", as "more moral". These include vaginal coitus between husband and wife even though not with the purpose to procreate, but rather for conupiscentia, which is more acceptable than vaginal coitus with a prostitute.

Sex which is para fusin, such as anal and oral sex, is more acceptable, though still contentemptable (execrabiliter), with a prostitute than with a wife. For the wife it is more shameful (turpior) if she causes her husband to have sex "para fusin" with her than if he should have it with another woman. Here Augustine's androcentric perspective and the honour-shame codes of his day seem to come through stronger than his own theory of marriage as having a three-fold purpose: (1) progeny (proles), (2) fidelity (fides) and (3) the sacramental bond (sacramentum) (Augustinus, De bono coniugali 3.3). The crux of this androcentrism is that marriage gains "moral value" when children (sons are preferable to daughters) are born (cf Børresen [1968] 1981:94-123). Jesus' and Paul's argument that it is better not to marry was probably motivated by the idea an unmarried person could be more dedicated to God. Paul's reason for proposing abstinence within marriage was for more time for prayer (1 Cor 7:5). Jesus' and Paul's choice for celibacy was rather subversive within their context. The positive evaluation of celibacy and ascetism with an aversion to sex and sexual desire was Gnostic ideology which only emerged in the second century. The Roman Catholic Church based its ideology of celibacy for priests on the sacrament of ordination (promise of fidelity analogical to marriage vows). Monks' and nuns' celibacy was not seen as a sacrament (permanent). Rather the analogy for them was the metaphor of "holy marriage" in Ephesians 5 (influenced by the hieros gamos in the mystery religions - see Heinrich Schlier's [1957] Commentary on the Letter to the Ephesians).

The earliest witness to divorce being forbidden for Christians on the grounds that marriage is permanent (a "sacrament") that I know of, is in Augustine's (401 CE) De bono coniugali 32.24. Here Augustine speaks against, among others, Jovian and the "Pelagian" Julian for whom marriage was as honourable as virginity (as pure).

Thomas Aquinas (Summa theologiae II-II Q.154) worked out the idea of marriage as "sacrament" for the Roman Catholic Church in the 13th century CE (see Schillebeeckx 1965). Marriage was already declared a sacrament in the 12th century CE. Already in the 4th century CE the Latin Vulgate translates mysterion in Ephesians 5:32 as sacramentum. The meaning of this word in Greek is: something which is not immediately visible or clear on the surface. Therefore it could also be translated with words such as "deep", "riddle", or "secret". Platonic philosophy has the notion that, what is essential, is not visible on the surface, but is invisible, deep under surface. For Paul the spirit 
(pneuma) is the godly essence of "nature" (sarx) which is the visible, the created natural side of being human. Paul's ecclesiology (e.g. 1 Cor 12 and $\mathrm{Rm} 12$ ) is built on this notion, underpinned by his evangelical theology that Christ's death on the cross meant the death of the sarkikos existence and that Christ's resurrection was the beginning of the new spiritual dimension.

Believers partake in this new creation by being baptized in the death of Christ (Rm 6), and by means of the gift of the Spirit of God who is also the Spirit of Christ (Rm 8). In the new creation visible categories such as Greek or Judean, slave or free, rich or poor, young or old, male or female are not determinative of whether a person may partake in the salvific presence of God within the created reality (Gl 3). The author of Ephesians (deutero-Pauline) shares with Paul the idea of the distinction between pneuma and sarx. Even though his ecclesiology differs from that of Paul (on account of the development of the institutionalisation of the church and the social roles of leaders and lay people), he does take over Paul's idea that the visible faith community, characterised by a variety of social roles and positions, should be reminded of the invisible deeper essence of what the faith community is all about, namely its relationship with Christ. The word mysterion is used by the author to denote this deeper meaning. It is therefore not possible to base the later sacramentalisation of marriage or the mystification of the church as godly institute on the word mysterion as it is used within the context of Ephesians 5. This is, however, what had happened in church and society - also in Protestant churches (see the classical marriage formulary and Karl Barth's interpretation of Ephesians 5 in light of Genesis 1 and 2).

The Latin sacramentum (4th century translation of mysterion) means "pledge of fidelity". It originated from Roman military history. A commitment was expected from a soldier when he was sworn into a military unit (Thatcher 1999:40). The notion of marriage as indissoluble because of its sacramental status took hold because of the connection of the word sacrament with marriage against the background of Ephesians 5. The Roman Catholic debate on whether divorce should be permissible, revolves around the question as to what it is that binds husband and wife: is it mutual consent, the priestly blessing, or coitus? The reception history of the meaning of sacramentum as "saving grace" through Augustine to Aquinas can be understood in terms of the dialectical pair remedium and medicinum. The sacrament was understood to heal (reconcile sinners with God) and save from the sin of conupiscentia (see Mackin 1982:32; see Schüssler Fiorenza 1991:316). In the same vein Gregory of Nyssa in his work, Ode virginitate, sees even a "happy marriage" as "filled with woe" and John Chrysostom calls virginity life and marriage death (see Hart 1990). 
When defending polygamy, Augustine (De bono coniugali 17.20) does not go back to Jesus, but to Paul. He bases his argument on Romans 7:1-6, 7-13 when he explains that polygamy (polygyny, not polyandry) could, under certain circumstances be regarded as "not against the nature of marriage" (natura nuptiarum) since, biologically speaking many women can have children with one man. Augustine's logic follows a hidden "natural and social" norm (ratio naturalis vel socialis): in nature and according to cultural customs some people are dominated by others. In some societies a slave owner will have only one slave whereas in others (as in Augustine's world where Roman cultural customs prevailed) he could have many slaves. Similarly, in some societies a man dominates only one woman (monogamy) while in others he can be the master of many women (polygyny). Therefore, according to Augustine, social customs would determine whether monogamy of polygamy would be acceptable. Polygamy is not necessarily contra naturam nuptiarum. As far as women are concerned, their obedience to one man (polygyny, as opposed to polyandry) is, however, based on the relationship between God and human beings and not on the possibilities of procreation.

Augustine's "morality argument" based on his ideology of gender subordination brings him to use 1 Corinthians 7:4-5 in order to show that a man has authority over a woman in marriage, but a woman does not have authority over the man (De bono coniugali 5.5 ). On these grounds he deems polygyny in the Old Testament acceptable and is of the opinion that women are obliged to pay their husbands their "fleshly dues" (Augustine, De bono coniugali 5.5). Though marriage in this view was regarded as a sacrament, it was not seen as particularly spiritual. It was seen as "more of a remedy for sin than a recipe for righteousness" (Witte 1997:4). Remaining celebate was much more spiritual and seen as a "higher" lifestyle. Having children would only detract from one's focus on prayer and contemplation and was therefore a "lower" form of living. Only those who could refrain from such mundane activities such as getting married, having sex and having children were deemed "worthy" of the church offices. Witte (1997:4) puts it as follows: "Celibacy was something of a litmus test of spiritual discipline and social superiority."

The comprehensive Catholic canon law of marriage was formally accepted by the Council of Trent in 1563. It significantly influenced Western marriage in the following centuries (Witte 1997:4). The mixture of a sacramental and a naturalist view of marriage resulted in the banning of contraception and abortion since they violated the God-given natural function of procreation. The canon law also defined "unnatural relations" such as, for example, incest and bestiality. Since it was regarded a sacrament, "valid" 
The "sanctity" of marriage - an archaeology of a socio-religious construct

marriages could not be dissolved, whereas "invalid" marriages, such as, for example, between a Christian and non-Christian, could be dissolved?

\subsection{The Protestant models}

\subsubsection{Introduction}

Protestant views on marriage concurred with the Catholic naturalistic perspective in that the union of man and woman was also seen to have been created by God for the purposes of procreation and protection. The contractual facet of marriage as a mutual agreement between individuals was also accepted. Where the Protestant view differed from the Catholic was on the points of marriage as a sacrament and marriage as subordinate to celibacy (Witte 1997:5). The latter was not seen as having any spiritual merit and therefore was not a prerequisite for clergy. Rather than a sacrament, marriage was seen as a social institution, nevertheless ordained by God. As such it had responsibilities similar to those of other social institutions, such as the church and the state. The three main Protestant traditions each integrated the three perspectives on marriage of the natural, the contractual and the religious in their own way.

\subsubsection{The Lutheran model}

From the time of Martin Luther himself the Lutheran tradition constructed a social model of marriage on the basis of the Lutheran idea of the separation of the two separate kingdoms, the heavenly and the earthly (see Douglass 1985; 1991:231-232; Köstenberger 1997:107-144). Marriage belonged to the earthly kingdom of creations. Therefore it had no redemptive value and was not sacred. God had ordained marriage for social purposes (see Buitendag 2007:445-461). Witte (1997:5) puts it as follows: "Marriage revealed to persons their sin and their need for God's marital gift. It restricted prostitution, promiscuity, and other public sexual sins. It taught love, restraint, and other public virtues. All fit men and women were free to enter such unions, clerical and lay alike. Indeed, all persons were spiritually compelled to marry when they came of age, unless they had the rare gift of continence."

Another logical consequence of this theology is that marriage would be an affair of the state, not the church. Civil law would therefore be the authority governing marriage. The church had no legal authority over marriage (Witte 1997:6). The church permitted divorce. Both marriage and divorce were to be public events with witnesses present and official registration or dissolution by the civil authority. 


\subsubsection{The Calvinist model}

In the Calvinist tradition, originating from Geneva in the mid-sixteenth century, a covenantal model of marriage developed (see Potter 1986:725-730; Douglass 1991:249-251). Marriage was not regarded as a sacrament, but as a covenantal association not only of the couple themselves, but of the entire community (Witte 1997:7). A couple got married before God, "rendering all marriages triparty agreements, with God as third-party witness, participant, and judge" (Witte 1997:7). Parents, who were charged by God with responsibility for children, gave their consent and witnesses as God's priests, formed part of the event. The minister, God's spiritual representative, blessed the marriage and impressed their spiritual duties on the couple. The state was responsible for the legal registration of the marriage. All parties had to fulfil their role in order for a marriage to be legitimate. Witte (1997:7) captures the spirit of the covenantal model as follows:

The covenant of marriage was grounded in the order of creation and governed by the law of God. At creation, God ordained the structure of marriage to be a lifelong union between a fit man and a fit woman of the age of consent. God assigned to this marriage the interlocking purposes of mutual love and support of husband and wife, mutual procreation and nurture of children, and mutual protection of both parties from sexual sin. Thereafter, God set forth in reason, conscience, and the Bible a whole series of commandments and counsels for proper adherence to this ideal created structure and purpose of marriage.

In the Calvinist tradition marriage is regarded as a holy bond, though no sacrament. It was seen as a contract between two consensual parties, though it was also more than a contract. God, who was seen as part of the marriage covenant, determined the form, forum, and function of marriage (Witte 1997:8). The freedom of the individuals was limited to the choice of a marriage partner. The Calvinist view differs from the Lutheran in that it added a spiritual dimension to marriage as part of the earthly kingdom. As a result Calvinist practice was stricter, aiming to ensure that only those who were fit could enter into the covenant of marriage, that the partners conduct themselves in the right way while married, and that only "innocent" parties could petition for the dissolution of the covenant (Witte 1997:8).

\subsubsection{The Anglican model}

The Anglican commonwealth model had its origin in the period between 1540$1640 \mathrm{CE}$. The three models of the sacramental, social and covenantal were 
integrated and superseded. Witte (1997:8) puts it as follows: "Marriage was at once a gracious symbol of the divine, a social unit of the earthly kingdom, and a solemn covenant with one's spouse." Marriage was for the common good not only of the couple and their children, but simultaneously also for the church and the state. The family as "little commonwealth" was to provide love, security and service to the family members and had the extended task of instilling Christian norms and habits in the church, society and state (Witte 1997:8). The commonwealth model of marriage confirmed traditional hierarchies. The "little commonwealth" was subordinate to the "great commonwealth". In order to maintain the stability of both the dissolution of marriage was not permitted.

The commonwealth model of marriage changed with the changes which took place in the commonwealth itself. Principles of equality and "rights" took the place of traditional hierarchies. A violation of rights of individuals could lead to the collapse of systems. Witte (1997:10) calls this process "the incremental liberalization of English marriage law" which lead to the development of "the contractarian model of marriage during the Enlightenment era".

\subsubsection{The Enlightenment model}

During the eighteenth to the twentieth century the emphasis was increasingly placed on the contractual aspect of marriage. Enlightenment thinkers saw the essence of marriage not as a sacrament, covenant or service to the social community, but as the choice of two people to enter into an intimate relationship. What this relationship should look like, was not preordained by God or nature, or prescribed by the church, state, tradition or community, but by the parties themselves. They would obey the general rules and norms of civil society, such as respect for life, liberty, property, safety, health and the general welfare of people (Witte 1997:10). For the rest the finer points of their relationship and life together would be worked out by themselves.

This kind of thinking lead to criticism of the traditional Western (religious) ideas of marriage. Issues such as parental consent, the role of the church, the requirement of formal witnesses and the absolute position of heterosexual monogamy were questioned. The full equality of men and women was not negotiable. According to Witte (1997:11-12) these ideas were too radical to really transform the inheritance of the nineteenth century. They did, however lead to greater protection for women and children, concerning both their bodies and their property, as well as deciding the agenda for marriage reform in the twentieth century. The emphasis was increasingly placed on what the parties who enter into marriage wanted. No external 
authorities such as the church, parents or the community had the primary say any longer. Consequences of these shifts were matters such as prenuptial contracts, no-fault divorces and the right to privacy concerning sexual matters. Other sexual orientations than the heterosexual have been increasingly accepted. Nonconsensual conduct has become punishable by the state up to the point where the possibility of rape within marriage has been conceded by the state.

Witte (1997:12) argues that this movement "from sacrament to contract" as he puts it, does not mean that marriage has been "secularised". He points out that the medieval Catholic model was as secular in its theology and law of marriage as the Enlightenment contractarian model. The movement that has taken place is, according to him, "not so much [one] of incremental secularization as of intermittent resacralization of Western marriage .... To laicize, temporalize, or politicize marriage is not the same thing as to secularize marriage" (Witte 1997:12). Every model, including contemporary trends, has been inspired by religious convictions concerning marriage and sexuality. As the theology and laws of marriage have evolved in changing times, the challenge has always been to find a new balance between order and liberty, orthodoxy and innovation regarding sexual and family norms and habits (Witte 1997:15). The challenge presents itself again in today's world which has, in a sense evolved too quickly for theologies on sexuality, marriage and family to keep up. In this respect the law has probably done a better job.

\section{PAVING THE WAY FOR NON-ESSENTIALISTIC APPROACH}

The article begins with criticism on the essentialism underlying the emphasis that Christopher Roberts places on the sexual difference between male and female in his "moral theology of marriage". This emphasis on difference is tantamount to a "dual anthropology". Rosemary Ruether $(1975,1983,1991)$ is known for her feminist critique on dual anthropology. She proposes a "one nature" anthropology. The difference between the two views is articulated as follows by Coll (1994:70): "Dual-nature anthropology suggests that women and men are of different natures determined by God and that these different natures determine what is appropriate for each sex ... (S)ingle-nature theory ... holds that most differences between women and men are culturally defined and therefore open to change". According to the single-nature theory what is termed "masculine" or "feminine" has actually been culturally constructed (cf 
Mead 1939). Coll $(1994: 80,81)$ is critical of dual-nature theory because it is inherently essentialistic and patriarchal.

Emphasising sexual difference as central to the theological discussion on sexuality and marriage perpetuates the view of a dual anthropology. It is essentialistic when the biological difference between men and women also determine the relationship between God and human beings as belonging to two different sexes. The consequence is that sexual difference is also overemphasized in human interaction. The role of changing social constructs is not taken into account. Different perspectives on sexuality and the existence of a variety of forms and models and marriage arrangements are not taken into account. Patriarchal heterosexual marriage is absolutised and becomes a hegemony.

In order for human beings to create a "humane" society, critical theologians find it important to remain suspicious of a dehumanising status quo. In order to open up the possibility of authentic humanity for all people it is necessary to be aware that constructs and social patterns are human creations, not God-given structures. Therefore they have the potential to do harm or be evil (see Leroy Howe 1995:23). A dehumanising system will affect those with less and those with more power: "When the systems operative in a culture are demeaning and dehumanizing, a vicious circle is set in motion in which women and men are prevented from developing the full humanity to which they are called. At the same time fractured humanity is incapable of creating a society that is truly human" (Coll 1994:82).

Postmodern philosophy and theology create awareness of the harm that is done when human constructs are purported to be God-given and unchanging. It is therefore worth elaborating on the three "postmodern" approaches that Christopher Roberts (2007:185-231) rejects in his "theology of marriage". This will be done in another study.

\section{Works consulted}

Adler E J 1990. The background for the metaphor of covenant as marriage in the Hebrew Bible. PhD dissertation (UMI Dissertation Services.)

Ambrose [s a] 1952. Concerning widows 4.23, in Schaff, P \& Wace, $\mathrm{H}$ (eds), A select library of Nicene and Post-Nicene Fathers of the Christian Church. Grand Rapids, Ml: Eerdmans.

Audet, J P (ed) 1958. La Didachè: Instructions des Apôtres. Paris: Lecoffre Augustinus [s a]. De civitate Dei, XIV.10, 21, 22, in Dyson, R W 1998, Augustine, City of God, ed \& tr by R W Dyson. Cambridge: Cambridge University Press.

Augustinus [s a] 1952. Sermons on New Testament lessons, Sermon 1.22, in Schaff, $\mathrm{P} \&$ Wace, $\mathrm{H}$ (eds), A select library of Nicene and Post-Nicene Fathers of the Christian Church. Grand Rapids, MI: Eerdmans. 
Augustinus [s a] [1999]. The works of saint Augustine, part 1, vol 9: Marriage and virginity, tr by R Kearney. Hyde Park, NY: New City.

Augustinus [s a] [2003a]. De nuptiis et conupiscentia, in Brooten B J 2003, Nature, law, and custom in Augustine's On the good of marriage, in Matthews, $\mathrm{S}$ et al (eds), Walk in the ways of wisdom: Essays in honor of Elisabeth Schüssler Fiorenza, 181-193. Harrisburg, PA: Trinity Press International. (A Continuum imprint.)

Augustinus [2003b], De bono coniugali, in Brooten B J 2003. Nature, law, and custom in Augustine's On the good of marriage, in Matthews, S et al (eds), Walk in the ways of wisdom: Essays in honor of Elisabeth Schüssler Fiorenza, 181-193. Harrisburg, PA: Trinity Press International. (A Continuum imprint.)

Barth, K 1934-1964. Church Dogmatics, 4 volumes, tr by G W Bromiley et al. Edinburgh: T \& T Clark.

Batey, R 1961. The church, the bride of Christ. Ann Arbor, MI: University Microfilms.

Belkin, G S \& Goodman, N 1980. Marriage, family and intimate relationships. Chicago, IL: Rand McNally College Publishing Company.

Bennet, J C 1962. Review of Church Dogmatics III/4 by Karl Barth. Union Seminary Quarterly Review 18(1), 74-79.

Berkouwer, G C [1962] 1968. Man: The image of God, tr by D W Jellema. Grand Rapids, MI: Eerdmans. (Studies in Dogmatics.)

Bishop, C 2004. Seksualiteit en spiritualiteit: Ekstase, rituele en taboes. Groningen: Textcase.

Borg, M J 1987. Jesus - a new vision: Spirit, culture and the life of discipleship. New York: Haper \& Row.

Borg, M J 2003. The heart of Christianity: Rediscovering a life of faith. San Fransisco, CA: HarperSanFransisco.

Børresen K E [1968] 1981. Subordination and equivalence: The nature and role of woman in Augustine and Thomas Aquinas, tr by $\mathrm{C} \mathrm{H}$ Talbot. Washington, DC: University Press of America.

Botha, A \& Dreyer Y 2007. Demistifikasie van die metafoor "die kerk as bruid". HTS 63(3), 1239-1274.

Botéro, J \& Petschow, H 1972-5. sv Homosexualität. Reallexikon der Assyriologie IV, 459-668.

Brooten, B J 1996. Love between women: Early Christian responses to female homoeroticism. Chicago, IL: University of Chicago Press.

Brooten B J 2003. Nature, law, and custom in Augustine's On the good of marriage, in Matthews, $\mathrm{S}$ et al (eds), Walk in the ways of wisdom: Essays in honor of Elisabeth Schüssler Fiorenza, 181-193. Harrisburg, PA: Trinity Press International. (A Continuum Imprint.)

Buitendag, J 2007. Marriage in the theology of Martin Luther - worldly yet sacred: An option between secularism and clericalism. HTS 63(2), 445-461.

Chrysostom, J [s a] 1952. Homily on Matthew, in Schaff, P \& Wace, $\mathrm{H}$ (eds), A select library of Nicene and Post-Nicene Fathers of the Christian Church 10, 443444. Grand Rapids, MI: Eerdmans.

Chrysostom, J [s a] 1986a. Sermon on Marriage, in St John Chrysostom on marriage and family life. Crestwood, NJ: St Vladimir's Press. 
Chrysostom, J [s a] 1986b. Homily 20 on Ephesians, in St John Chrysostom on marriage and family life, 54-55. Crestwood, NJ: St Vladimir's Press.

Chrysostom, J [s a] 1986c. How to choose a wife, in St John Chrysostom on marriage and family life, 89-114. Crestwood, NJ: St Vladimir's Press.

Coll, R A 1994. Christianity and feminism in conversation. Mystic, CT: Twenty-Third Publications.

Connolly, R H (translator) 1929. Didascalia Apostolorum. Oxford: Clarendon.

Countryman, W L [1988] 1990. Dirt, greed \& sex: Sexual ethic in the New Testament and their implications for today. First paperback edition. Minneapolis, MN: Fortress.

Countryman, W L 2007. Dirt, greed \& sex: Sexual ethic in the New Testament and their implications for today. Rev edition. Minneapolis, MN: Fortress.

Crosby, J 1976. A marriage wake: Myths that die hard, in Cox, F D (ed), American marriage: A changing scene, 85-96. $2^{\text {nd }}$ edition. Dubuque, lowa: Wim C Brown.

Douglass, J D 1985. Women, freedom, and Calvin. Philadelphia, PA: Westminster. Douglass, J D 1991. The image of God in women as seen by Luther and Calvin, in Børresen, K E (ed), Image of God and gender models in Judaeo-Christian tradition. Oslo: Solum Forlag.

Douglass, J D 1991. The image of God in women as seen by Luther and Calvin, in Børresen, K E (ed), Image of God and gender models in Judaeo-Christian tradition. Oslo: Solum Forlag.

Dreyer, Y 2005. Sexuality and shifting paradigms - setting the scene. HTS 61(3), 729-751.

Dreyer, Y 2007a. Karl Barth's male-female order as assymetrical theoethics. HTS 63(3), 1493-1521.

Dreyer, Y 2007b. Karl Barth's male-female order: A kingpin of dogmatic disparity. HTS 63(3), 1523-1547.

Fitzgerald, A 1972. The mythological background for the presentation of Jerusalem as a queen and false worship as adultery in the Old Testament. CBQ 34, 403416.

Hart, M D 1990. Reconciliation of body and soul: Gregory of Nyssa's deeper theology of marriage. Theological Studies 51(3).

Howe, L T 1995. The image of God: A theology for pastoral care and counseling. Nashville, TN: Abingdon.

Human, D J 2007. Om by die grense van die "ek" verby te steek ....: Erotiek en seksualiteit in die Ou Nabye-Ooste, in in Vos, C \& Human, D (reds), Liefde is die grootste: Oor erotiek en seksualiteit, 16-45. Pretoria: Protea Boekwinkel.

Huser, W R \& Grant, C W 1978. A study of husbands and wifes from dual-career and traditional-career families. Psychology of women Quarterly 3(1), 78-89.

Goode, W J 1963. World revolution and family patterns. New York: Free Press.

Goode, W J 1976. Family patterns and human rights, in Cox, F D (ed), American marriage: A changing scene, 159-167. 2nd edition. Dubuque, lowa: Wim C Brown.

Johnson, E E 1992. Ephesians, in Newsom, C A \& Ringe, S H (eds), The women's Bible commentary, 338-342. Louisville, KY: Westminster.

Kearney, R (translator) 1999. The works of saint Augustine, part 1, vol 9: Marriage and virginity. Hyde Park, NY: New City. 
Kohn, M 1969. Classes and conformity: A study in values. Hoewood, IL: Dorsey.

Köstenberger, A J 1997. Ascertaining women's God-ordained roles: An interpretation of 1 Timothy 2:15. Bulletin for Biblical Research 7, 107-144.

Kramer, S N 1969. The sacred marriage rite. Bloomington, IN: University of Indiana Press.

Lewes, K 2003. Homosexuality, homophobia, and gay-friendly psychoanalysis, in Moss, D (ed), Hating in the first person plural: Psychoanalytic essays on racism, homophobia, misogyny, and terror. New York: Other Press.

Libby, R W \& Whitehurst, R N (eds) 1977. Marriage and alternatives: Exploring intimate relationships. Glenview, IL: Scott, Foresman.

Livingstone, A 1968. Mystical and mythological explanatory works of Assyrian and Babylonian scholars. Oxford: Clarendon.

Lyotard, J-F [1979] 1984. The postmodern condition, tr by Gennington \& B Massumi. Minneapolis, MN: University of Minnesota Press. (Theory and History of Literature 10.)

Lyotard, J-F 1989. Lessons in pragmaticism, tr by D Macey, in Benjamin, A (ed), The Lyotard reader, 122-154. Oxford: Basil Blackwell.

Lyotard, J-F 1993. The postmodern explained, tr and ed by J Pefanis \& M Thomas. Minneapolis, MN: University of Minnesota Press.

Mackin, T 1982. Marriage in the Catholic Church: What is marriage? New York: Paulist.

McCarthy, D M 1997. Homosexuality and the practices of marriage. Modern Theology 13(3), 371-397.

McCarthy, D M 2001. Sex and love in the home: $A$ theology of the household. London: SCM.

McCarthy, D M 2002. The relationship of bodies: A nuptial hermeneutics of same-sex union, in Rogers, E F (ed), Theology and sexuality: Classic and contemporary readings, 200-216. Oxford: Blackwell.

Mead, M 1939. Sex and temperament in three primitive societies. New York: Morrow.

Müller, H P 1994. Menschen, Landschaften und religiöse Erinnerungsreste: Anschlußerörterungen zum Hohelied. ZThK 91, 375-395.

Murdock, G P 1949. Social structures. New York: Macmillan

Murdock, G P 1957. World ethnographic sample. American Anthropologist 59(4), 664-687.

Osiek, C \& Balch, D L 1997. Families in the New Testament world: Households and house churches. Louisville, KY: Westminster. (The Family, Religion, and Culture.)

Osiek, C 2002. The bride of Christ (Ephesians 5:22-33): A problematic wedding. BTB 2(1), 29-39.

Otto, E 1994. Theologisches Ethik des Alten Testaments. Stuttgart: Kohlhammer. (ThW 3/2.)

Otto, E 1995. Kritik der Pentateuch-Komposition. ThR 60, 161-193.

Otto, E 1996. Homosexualität im Alten Orient und im Alten Testament, in Otto, E \& Uhlig, S (Hrsg), Kontinuum und Proprium: Studien zur Sozial- und Rechtsgeschichte des Alten Testaments, 322-330. Wiesbaden: Harrassowitz. (Orientalia Biblica et Christiana 8.) 
Otto, E 2007. Homoseksualiteit in die Ou Nabye-Ooste en Ou Testament, vertaal deur A Groenewald, in Vos, C \& Human, D (reds), Liefde is die grootste: Oor erotiek en seksualiteit, 58-66. Pretoria: Protea Boekwinkel.

Potter, M 1986. Gender equality and gender hierarchy in Calvin's theology. Signs 1, 725-739.

Queen, S A \& Habenstein, R W 1974. The family in various cultures. $4^{\text {th }}$ edition. Philadelphia, PA: J B Lippincott.

Reynolds P L 1994. Marriage in the Western Church: The Christianization of marriage during the Patristic and Early Medieval Periods. Leiden: Brill.

Roberts, C C 2007. Creation and covenant: The significance of sexual difference in the moral theology of marriage. T \& T Clark International. (A Continuum imprint.) 2007.

Roberts, A \& Donaldson, J (eds) 1885a. The Ante-Nicene Fathers 3. Buffalo, NY: The Christian Literature Publishing Co.

Roberts, A \& Donaldson, J (eds) 1885b. The Ante-Nicene Fathers 2. Buffalo, NY: The Christian Literature Publishing Co.

Rogers, E 1999. Sexuality and the Christian body: Their way into the Triune God. Oxford: Blackwell.

Rogers, E 2004. Sactified unions: An argument for gay marriage. Christian Century 121(12), 26-29.

Ruether R R 1975. New woman/New earth: Sexist ideologies and human liberation. New York: Seabury.

Ruether, R R 1983. Sexism and God-talk: Toward a feminist theology. Boston, MA: Beacon.

Ruether, R R 1991. Imago Dei, Christian tradition and feminist hermeneutics, in Børresen, K E (ed), Image of God and gender models in Judaeo-Christian tradition. Oslo: Solum Forlag.

Schaff, P \& Wace, H 1952 (eds). The seven ecumenical councils. Grand Rapids, MI: Eerdmans.

Schillebeeckx, E 1965. Marriage: Human reality and saving mystery. London: Sheed \& Ward.

Schlier H 1957. Der Brief an die Epheser: Ein Kommentar. Düsseldorf: PatmosVerlag.

Schüssler Fiorenza, F 1991. Marriage, in Schussler Fiorenza, F \& Galvin, J P (eds), Systematic Theology: Roman Catholic perspectives, vol 2I, 305-346. Minneapolis, MN: Fortress.

Spiro, M E 1956. Is the family universal? American Anthropologist 56, 893-846.

Stammkötter, F-B \& Müller, C 2004. s v F. als "Regel" (besonders bei A[ugustinus]' Verhältnisbestimmung von Mann und Frau), in Mayer, C (Hrsg), AugustinusLexikon, Vol 3, Fasc 1.2, 49-52.

Stegemann, E W \& Stegemann W [1995] 1999. The Jesus movement: A social history of its first century, tr by $\mathrm{O} C$ Dean. Edinburgh: $T$ \& $T$ Clark.

Stephens, W N 1963. The family in cross-cultural perspectives. New York: Holt, Rinehart \& Winston.

Stone, K 2000. Sexuality, in Adam, A K M (ed), Handbook of postmodern biblical interpretation. St Louis, MO: Chalice.

Thatcher, A 1999. Marriage after modernity: Christian marriage in postmodern times. Sheffield: Sheffield Academic Press. 
Van Aarde, A G 2007. Die hervorming van die huwelik deur Luther teen die agtergrond van die klassieke siening en kategorieë rakende godsdienshuwelik-seksualiteit. Ongepubliseerde voordrag, Voortgesette Teologiese Toerusting. Hervormde Teologiese Kollege, Universiteit van Pretoria, November 2007.

Van Dijk-Hemmes, F 1989. The imagination of power and the power of imagination. An intertextual analysis of two biblical love songs: The Song of Songs and Hosea 2. JSOT 44, 75-88.

Ward, G 1997. Postmodernism. London: Hodder Headline. (Teach Yourself.)

Ward, G 1998. The erotics of redemption - after Karl Barth. Theology and Sexuality 8, 52-72.

Weitzman, L J 1975. To love, honor, and obey? Traditional legal marriage and alternative family forms. The Family Coordinator 24(4), 531-538.

Wengst, K 1987. Paulus und die Homosexualität. Zeitschrift fũr Evangelische Ethik 31.

White, R J 1975. The interpretation of dreams: Oneirocricica by Artemidorus. Park Ridge, NY: Noyes.

Winkler, J J 1990. The constraints of desire: The anthropology of sex and gender in ancient Greece. New York: Routledge.

Winter, U 1983. Frau und Göttin: Exegetische und ikonographische Studien zum weiblichen Gottesbild im Alten Testament und in dessen Umwelt. Göttingen: Vandenhoeck \& Ruprecht.

Witte, J 1997. From sacrament to contract: Marriage, religion, and law in the Western tradition. Louisville, KY: Westminster John Knox. 